\title{
Evaluation between Betel Quid and Pan Masala/Gutkha Habitual Chewers with OSMF
}

\author{
G Supadminidevi, K Jayanthi, Bina Shah, R Kamala
}

\begin{abstract}
Introduction: The increasing use of pan masala/gutkha, a mix of tobacco and a less moist form of betel quid lacking the betel leaf, is associated with an earlier age of onset of oral submucous fibrosis. Hence, current study was conducted to evaluate and compare clinical, histopathological and cytological features of OSMF due to betel quid (BQ) and pan masala/gutkha chewing (PMG).
\end{abstract}

Materials and methods: Patients who had habit of chewing $B Q$ or $P M G$ and who were suffering from OSMF were selected for the study. Buccal mucosal smears were obtained from 30 controls, $B Q$ and PMG chewers. Incisional biopsy was done on buccal mucosa of $B Q$ and $P M G$ chewers. The results were tabulated and statistically analyzed.

Results and observation: PMG chewing is associated with onset of OSMF at an early age than BQ chewing habit. Relatively large proportion of intermediate cells was present as compared to superficial cells of buccal mucosa in habitual chewers as compared to control. However, intermediate cells capable of proliferation were slightly higher in PMG chewers as compared to $B Q$ chewers. On histopathological examination connective tissue hyalinization is more frequently evident amongst $B Q$ chewers than PMG chewers.

Conclusion: Habitual chewing of PMG induces OSMF more rapidly than the traditional $B Q$.

Keywords: Betel quid, Pan masala/Gutkha, Oral submucous fibrosis.

How to cite this article: Supadminidevi G, Jayanthi K, Shah B Kamala R. Evaluation between Betel Quid and Pan Masala/ Gutkha Habitual Chewers with OSMF. World J Dent 2012;3(1):37-40.

\section{Source of support: Nil}

Conflict of interest: None declared

\section{INTRODUCTION}

OSMF (oral submucous fibrosis) is a chronic disease of the oral mucosa characterized by inflammation and progressive fibrosis of the lamina propria and deeper to connective tissues. ${ }^{1-4}$ Screening of about 24,422 subjects belonging to a semi-urban district of Sangli in Western Maharashtra (India) revealed that $2.5 \%$ of the population studied had one or more oral lesions associated with prosthetic use, trauma and tobacco consumption, etc. Among which 75 had leukoplakia, 152 had OSMF (0.6\%), 14 had both leukoplakia and OSMF, 82 had oral squamous cell carcinoma. ${ }^{5}$ The increasing use of pan masala/gutkha, a mix of tobacco and a less moist form of betel quid lacking the betel leaf, is associated with an earlier age of onset of OSMF. ${ }^{6,7}$ Hence, current study was conducted to evaluate and compare clinical, histopathological and cytological features of OSMF due to betel quid (BQ) and pan masala/ gutkha chewing (PMG).

\section{METHODOLOGY}

Patients who had habit of chewing BQ or PMG and who were suffering from OSMF were selected for the study. A total of 30 patients who were PMG chewers in the age range of 19 to 48 years (average of 30 years), 30 patients with BQ chewing habit in the age range of 20 to 72 years (average of 40 years) and 30 controls were included in the study. Following criteria were used to clinically diagnose OSMF: ${ }^{8}$

a. Varying degrees of burning sensation

b. Limited mouth opening

c. Presence of pallor on oral mucous membrane (OMM)

d. Presence of palpable fibrous bands

e. Lack of pliability of oral mucosa.

After preliminary examination patients with $\mathrm{BQ} / \mathrm{PMG}$ chewing habit for more than 6 months were selected for the study. The clinical interincisal distance was grouped as follows: ${ }^{1,8}$

Group-I: $>35 \mathrm{~mm}$ of maximum interincisal distance Group-II: $16-35 \mathrm{~mm}$ of maximum interincisal distance Group-III: 9-16 mm of maximum interincisal distance Group-IV : $<9 \mathrm{~mm}$ of maximum interincisal distance

Subjects included in the study were asked to sign the consent form. Subjects with the history of smoking and suffering from any medical or systemic illness were excluded from the study. Later buccal mucosal smears were obtained from 30 controls, BQ and PMG chewers. Incisional biopsy was done on buccal mucosa of BQ and PMG chewers. The results were tabulated and statistical analysis was done with ANOVA.

\section{RESULTS AND OBSERVATION}

In the present study, it was interesting to note that average age in PMG chewers was less than 30 years and in BQ chewers was 40 years (Table 1). Hence, PMG chewing is associated with onset of OSMF at an early age than BQ chewing habit. Daily intake of PMG and BQ ranged from minimum of $8 \mathrm{gm} /$ day to $40 \mathrm{gm} /$ day (Table 2). Evaluation of areas affected in OSMF cases revealed buccal mucosa, 
retromolar area and lips were the maximum affected areas (Table 3). Interincisal distance was significantly reduced in both study groups, as compared to controls and incidence of group-III was more in PMG chewers (Tables 4 and 5). In the present study, patients mainly complained of moderate to severe burning sensation, inability to eat spicy food, stiffness of oral mucosa and inability to open the mouth partially.

The cells of epithelium consist of two functional populations: Progenitor (whose function is to divide and provide new cells) and maturing population (whose cells are continually undergoing a process of differentiation or maturation to form a protective surface layer). In the current study, relatively large proportion of intermediate cells was present as compared to superficial cells of buccal mucosa in habitual chewers as compared to control. However, intermediate cells capable of proliferation were slightly higher in PMG chewers as compared to BQ chewers (Table 6 and Fig. 1).

On histopathological examination connective tissue hyalinization is more frequently evident amongst $\mathrm{BQ}$ chewers than PMG chewers. The frequency with which epithelial atypism has occurred is almost similar to both the groups. Epithelial atypism is a definite finding in PMG chewers of OSMF whereas only epithelial atrophy is a definite finding in $\mathrm{BQ}$ chewers. There was less chance of blood vessel getting obliterated in BQ chewers with OSMF as compared to PMG chewers (Fig. 2).

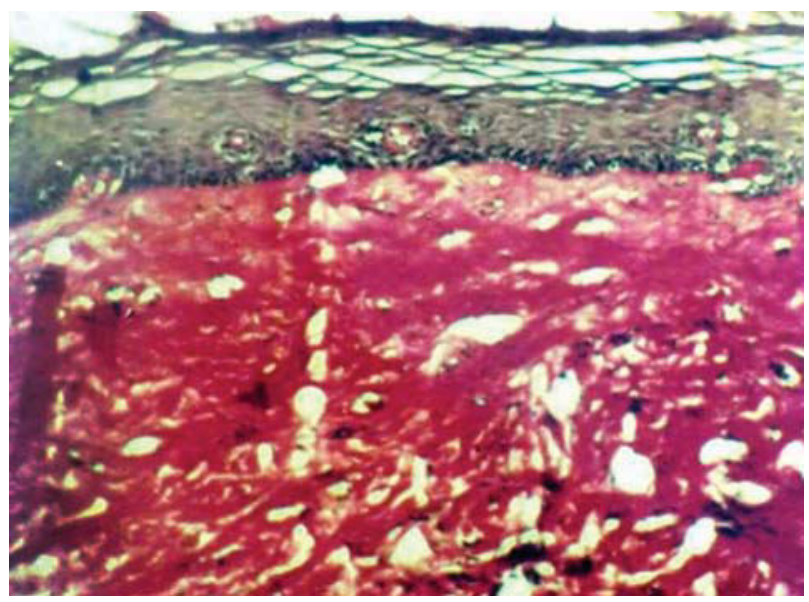

Fig. 1: Buccal mucosal smear of OSMF patients with PMG chewing habit revealing numerous intermediate cells

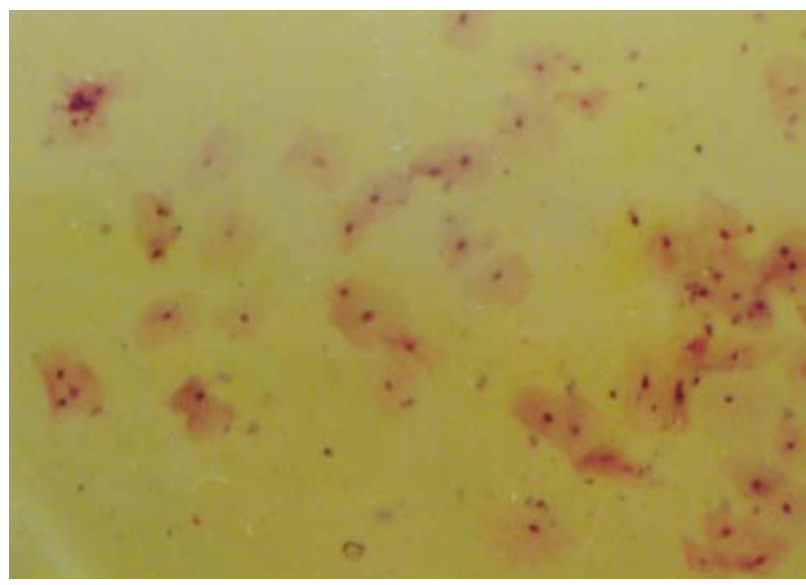

Fig. 2: Histopathological features of OSMF revealing juxta-epithelial hyalinization of connective tissue

\begin{tabular}{|c|c|c|c|c|c|c|}
\hline \multirow{2}{*}{$\begin{array}{l}\text { Age group } \\
\text { (years) }\end{array}$} & \multicolumn{2}{|c|}{ Pan masala/gutkha } & \multicolumn{2}{|c|}{ Betel quid chewers } & \multicolumn{2}{|c|}{ Control } \\
\hline & No. of cases & Percentage & No. of cases & Percentage & No. of cases & Percentage \\
\hline $20-30$ & 20 & 66 & 9 & 30 & 16 & 53.4 \\
\hline $30-40$ & 8 & 26.6 & 8 & 26.6 & 5 & 16.6 \\
\hline $40-50$ & 2 & 6.7 & 9 & 6.7 & 9 & 30 \\
\hline $50-60$ & - & - & 1 & - & - & - \\
\hline$>60$ & - & - & 3 & - & - & - \\
\hline Total & 30 & 100 & 30 & 100 & 30 & 100 \\
\hline
\end{tabular}

Table 2: Data of chewing products available in market

\begin{tabular}{|c|c|c|c|c|}
\hline Chewing product & $\begin{array}{l}\text { Average total } \\
\text { weight per packet }\end{array}$ & Betel nut & Tobacco & Other ingredients \\
\hline Betel quid & $4.25 \mathrm{gm}$ & $0.7 \mathrm{gm}$ & $0.4 \mathrm{gm}$ & $\begin{array}{l}\text { Betel leaf } \\
\text { Rassy } \\
\text { Lime } \\
\text { Kesar } \\
\text { Silver }\end{array}$ \\
\hline $\begin{array}{l}\text { Pan masala/ } \\
\text { gutkha }\end{array}$ & $3.9 \mathrm{gm}$ & $2 \mathrm{gm}$ & $1.8 \mathrm{gm}$ & $\begin{array}{l}\text { Catechu } \\
\text { Lime } \\
\text { Spices } \\
\text { Flavor }\end{array}$ \\
\hline
\end{tabular}


Table 3: Evaluation of areas affected in OSMF cases

\begin{tabular}{|c|c|c|c|c|c|c|}
\hline \multirow[t]{2}{*}{ Area } & \multicolumn{2}{|c|}{ Pan masala/gutkha } & \multicolumn{2}{|c|}{ Betel quid } & \multicolumn{2}{|c|}{ Combined } \\
\hline & $\begin{array}{l}\text { No. of } \\
\text { cases }\end{array}$ & Percentage & $\begin{array}{l}\text { No. of } \\
\text { cases }\end{array}$ & Percentage & $\begin{array}{l}\text { No. of } \\
\text { cases }\end{array}$ & Percentage \\
\hline Only buccal mucosa & 1 & 3.3 & 5 & 16.7 & 6 & 10 \\
\hline $\begin{array}{l}\text { Buccal mucosa } \\
\text { and retromolar area }\end{array}$ & 5 & 16.7 & 8 & 26.7 & 13 & 21.7 \\
\hline $\begin{array}{l}\text { Buccal mucosa, retromolar } \\
\text { area and lips }\end{array}$ & 19 & 63.3 & 17 & 56.6 & 36 & 60 \\
\hline $\begin{array}{l}\text { Buccal mucosa, retromolar area, } \\
\text { lips and soft palate }\end{array}$ & 5 & 16.7 & - & - & 5 & 8.3 \\
\hline
\end{tabular}

Table 4: Grouping of OSMF cases under varying interincisal distance

\begin{tabular}{|c|c|c|c|c|c|c|c|}
\hline \multicolumn{2}{|c|}{ Mouth opening } & \multirow[t]{2}{*}{$\begin{array}{l}\text { Clinical } \\
\text { stage }\end{array}$} & \multirow[t]{2}{*}{ Group } & \multicolumn{2}{|c|}{$\begin{array}{c}\text { Pan masala/gutkha } \\
\text { chewers (PMG) }\end{array}$} & \multicolumn{2}{|c|}{$\begin{array}{l}\text { Betel quid chewers } \\
\text { (BQ) }\end{array}$} \\
\hline $\begin{array}{l}\text { Maximum } \\
(\mathrm{mm})\end{array}$ & $\begin{array}{l}\text { Minimum } \\
(\mathrm{mm})\end{array}$ & & & $\begin{array}{l}\text { No. of } \\
\text { cases }\end{array}$ & Percentage & $\begin{array}{l}\text { No. of } \\
\text { cases }\end{array}$ & Percentage \\
\hline$>35$ & $>30$ & Very early & Group I & - & - & 1 & 3.3 \\
\hline $16-35$ & $12-30$ & Early & Group II & 25 & 83.3 & 28 & 93.4 \\
\hline $9-15$ & $7-11$ & Moderately advanced & Group III & 5 & 16.7 & 1 & 3.3 \\
\hline$<9$ & - & Advanced & Group IV & - & - & - & - \\
\hline
\end{tabular}

Table 5: Analysis of habitual chewers with OSMF

\begin{tabular}{|c|c|c|c|c|c|c|c|}
\hline \multirow{2}{*}{$\begin{array}{l}\text { Study } \\
\text { groups }\end{array}$} & \multirow{2}{*}{$\begin{array}{l}\text { No.of } \\
\text { subjects }\end{array}$} & \multirow{2}{*}{$\begin{array}{l}\text { Age } \\
\text { (years) }\end{array}$} & \multicolumn{3}{|c|}{ Daily intake } & \multirow{2}{*}{$\begin{array}{l}\text { Duration } \\
\text { of chewing }\end{array}$} & \multirow{2}{*}{$\begin{array}{l}\text { Interincisal } \\
\text { distance }(\mathrm{cm})\end{array}$} \\
\hline & & & Total & Betel nut & Tobacco & & \\
\hline Control & 30 & $33 \pm 10$ & & & & & $4.03 \pm 0.13$ \\
\hline PMG & 30 & $28.13 \pm 7.8$ & $12.35 \pm 2.73$ & $6.33 \pm 1.4$ & $5.7 \pm 1.26$ & $1.62 \pm 0.8$ & $1.99 \pm 0.45$ \\
\hline$B Q$ & 30 & $38.8 \pm 12.4$ & $17.29 \pm 5.3$ & $2.85 \pm 0.88$ & $1.63 \pm 0.84$ & $5.73 \pm 2.65$ & $2.24 \pm 0.55$ \\
\hline
\end{tabular}

Table 6: Cytological analysis of study groups

\begin{tabular}{lccr}
\hline Study groups & No. of subjects & \multicolumn{2}{c}{ Epithelial cells (\%) } \\
\cline { 3 - 4 } & & Superficial cells & Intermediate cells \\
\hline Control & 30 & $25.43 \pm 5.3$ & $74.43 \pm 4.84$ \\
PMG chewers & 30 & $5.6 \pm 1.64$ & $95.10 \pm 1.35$ \\
BQ chewers & 30 & $13.83 \pm 4.43$ & $86 \pm 4.03$ \\
\hline
\end{tabular}

\section{DISCUSSION}

Oral submucous fibrosis is a high-risk precancerous condition that predominantly occurs amongst Indians, Indians settled outside India, to a lesser extent in other Asiatics and sporadically in Europeans. This condition was first reported in India in 1953. In the literature a number of factors that include chilies consumption, arecanut chewing, autoimmunity and genetic predisposition have been implicated in the pathogenesis of submucous fibrosis. The prevalence of submucous fibrosis in random samples of the population in India is up to $0.4 \% .{ }^{1}$ The present study aimed to compare the differences in the presentation of OSMF in PMG and BQ chewers. Mean consumption duration in PMG chewers was $1.6 \pm 0.8$ years, whereas in BQ chewers was $5.73 \pm 2.65$ years. Hence, this difference in mean duration period indicates that $\mathrm{PMG}$ may induce OSMF in shorter duration than $\mathrm{BQ}$. This is because of increased dry weight of arecanut and tobacco contents in PMG as compared to BQ. Another probable reason behind delay in BQ chewers is use of betel leaf which contains beta-carotene and hydroxychavicol (antioxidants). ${ }^{9,10}$ According to few researchers betel leaf is a source of many effector molecules which possibly play an important role in the pathway of chemical carcinogenesis and which might also stimulate the factors responsible for regression of OSMF by delaying the onset in BQ chewers. ${ }^{3,11,12}$ On cytological examination relatively large population of superficial cell layer in oral mucosa was noted in BQ chewers than in PMG chewers, which could be probably due to presence of increased proliferation potential of superficial cells than in 
PMG chewers. Histopathological studies of silver staining nuclear organizing region (AgNOR) of mucosal biopsy samples of OSMF, neoplastic and leukoplakia tissues have shown that these analyses are directly proportional to the proliferation potential of cell and are second highest in OSMF. According to Rajendran $\mathrm{R}$ et al pooled mean AgNOR counts in advanced OSMF were higher than in moderately advanced cases. ${ }^{13}$

\section{CONCLUSION}

From the present study, a conclusion can be drawn that habitual chewing of PMG induces OSMF more rapidly than the traditional $\mathrm{BQ}$. This could possibly due to absence of betel leaf and much higher weight of PMG ingredients. The habit of chewing tobacco in the habitual form of PMG is emerging as a main threat to oral health, globally. Hence, adequate steps have to be taken to educate the population about the ill-effects of PMG and eradicate the disease. Current study was conducted on a small scale, but further research studies have to be conducted on large scale to know the exact statistical values.

\section{REFERENCES}

1. Paissat DK. Oral submucous fibrosis. Int J Oral Surg 1981;10(5):307-12.

2. Zain RB, Ikeda N, Gupta PC, Warnakulasuriya S, van Wyk $\mathrm{CW}$, Shrestha P, Axéll T. Oral mucosal lesions associated with betel quid, areca nut and tobacco chewing habits: Consensus from a workshop held in Kuala Lumpur, Malaysia. J Oral Pathol Med Jan 1999;28(1):1-4.

3. Yusuf H, Yong SL. Oral submucous fibrosis in a 12-year-old Bangladeshi boy: A case report and review of literature. Int J Paediatr Dent Jul 2002;12(4):271-76.

4. Mehta FS. Chapter 2.5, Oral Submucous Fibrosis. Textbook on tobacco associated oral lesions, published by Basic Dental Research Unit, Tata Institute of Fundamental Research, Jaypee Brothers Medical Publishers (P) Ltd, 1993;56-67.

5. Byakodi R, Shipurkar A, Byakodi S, Marathe K. Prevalence of oral soft tissue lesions in Sangli, India. J Community Health Feb 13, 2011.

6. Shaleen Chandra. Effect of duration of pan masala chewing habit on mouth opening. JIDA January 2011;5(1).

7. Babu S, Bhat RV, Kumar PU, Sesikaran B, Rao KV, Aruna P, Reddy PR. A comparative clinicopathological study of oral submucous fibrosis in habitual chewers of pan masala and betel quid. J Toxicol Clin Toxicol 1996;34(3):317-22.

8. Angadi PV, Rao S. Management of oral submucous fibrosis: An overview. Oral Maxillofac Surg Sep 2010;14(3):133-42.

9. Adhvaryu SG, Dave BJ, Trivedi AH. An in vitro assessment of the genotoxic potential of pan masalas. Indian J Med Res Apr 1989;90:131-34.

10. Seedat HA, van Wyk CW. Betel chewing and dietary habits of chewers without and with submucous fibrosis and with concomitant oral cancer. S Afr Med J 3 Dec 1988;74(11): $572-75$.

11. Amonkar AJ, Nagabhushan M, D’Souza AV, Bhide SV. Hydroxychavicol: A new phenolic antimutagen from betel leaf. Food Chem Toxicol Dec 1986;24(12):1321-24.

12. Seedat HA, van Wyk CW. Submucous fibrosis (SF) in ex-betel nut chewers: A report of 14 cases. J Oral Pathol May 1988;17(5):226-29.

13. Rajendran R, Nair SM. Silver-binding nucleolar organizer region proteins as a possible prognostic indicator in oral submucous fibrosis. Oral Surg Oral Med Oral Pathol Oct 1992;74(4): 481-86.

\section{ABOUT THE AUTHORS}

\section{G Supadminidevi}

Reader, Department of Oral Medicine and Radiology, Bangalore Institute of Dental Sciences, Bengaluru, Karnataka, India

\section{K Jayanthi}

Professor and Head, Department of Oral Medicine and Radiology Bangalore Institute of Dental Sciences, Bengaluru, Karnataka, India

\section{Bina Shah}

Senior Lecturer, Department of Oral Medicine and Radiology Bangalore Institute of Dental Sciences, Bengaluru, Karnataka, India

\section{R Kamala}

Senior Lecturer, Department of Oral Medicine and Radiology Bangalore Institute of Dental Sciences, Bengaluru, Karnataka, India

\section{CORRESPONDING AUTHOR}

G Supadminidevi, Reader, Department of Oral Medicine and Radiology, 5/3, Hosur Main Road, Near Nimhans, Lakkasandra Bengaluru-560029, Karnataka, India, Phone: 919480434709 e-mail: culdts@gmail.com 